\title{
Notes on necrophagous flies (Diptera: Calyptratae) associated to fish carrion in Colombian Amazon
}

\author{
Eduardo AMAT $^{1}$
}

\section{ABSTRACT}

In recent years, there has been an increasing number of studies on carrion fly communities due to their medical importance and as a consequence of the large number of studies on forensic entomology. Surprisingly few studies have adressed with the asynantropic flies of the Amazon, and none were done in Colombia. A faunistic study of asynantropic flies of the families Calliphoridae, Sarcophagidae, Muscidae and Fannidae in three different landscapes of the Colombian Amazon is presented, trapping effectiveness is assessed, and the first record of Mesembrinella batesi (Aldrich, 1922) and Fannia femoralis (Stein, 1897) from Colombia is reported.

KEY WORDS: Faunistic survey, non parametric estimators, Richness, Abundance, Modified Trap

\section{Notas sobre moscas necrófagas (Diptera: Caliptratae) associadas a carcaças de peixe na Amazônia Colombiana}

\section{RESUMO}

Apesar de existir uma quantidade considerável de estudos sobre dípteros decompositores devido a sua importância medica e ao avanço da entomologia forense, poucos dizem respeito as moscas asinantrópicas na Amazônia e nada foi feito na Colômbia. No presente trabalho é feito um estudo faunístico sobre moscas, principalmente das famílias Calliphoridae, Sarcophagidae, Muscidae e Fanniidae em três diferentes paisagens da Amazônia Colombiana, além do primeiro registro das espécies Mesembrinella batesi (Aldrich, 1922) e Fannia femoralis (Stein, 1897) para Colômbia e avaliação da amostragem utilizada.

PALAVRAS-CHAVE: levantamento faunístico, Estimadores não paramétricos, Riqueza, Abundância, Armadilha modificada. 
The decomposing activity of bacteria, fungi and carrion animal feedings is the main process by which nutrients are released and recycled from dead animals. Arthropods and mainly carrion feeding insects represent the most conspicuous element in this process (Nuorteva, 1977; Hanski, 1987). The role of necrophagous flies is ecologically important given their predominance, these community assemblages are very complex and highly competitive, usually dominated by one to three species (Hanski, 1987; Ives, 1991).

In recent years, studies on carrion flies have increase. However, these studies have focused on synantropic environments and dealt mainly with faunal succession, lifecycles and species growth rates (Richards, 2001). Few known studies have been made from asynantropic conservation areas of the Amazonian rain forest e.g., Paraluppi (1992); Esposito, (1999) on blow flies (Diptera: Calliphoridae). Knowledge of necrophagous flies in the Colombian Amazon is sparse and consists mainly of isolated records of a few species: Guimaraes (1977) reported six species of Mesembrinellinae, Baumgartner \& Greenberg (1984) reported the blowfly Chrysomya putoria in Leticia for the first time in Colombia; and recently Pape et al (2005) reported Hemilucilia segmentaria, Chloroprocta idioidea and seventeen species of flesh flies (Diptera:Sarcophagidae). Finally, Fannia obscurinervis (Diptera: Fannidae) hasbeen reported in the Colombian Amazon by Carvalho et al (2003) and Couri \& Winagraski (2005).

The study was carried out at the Biological Station "El Zafire" National University of Colombia (Leticia branch) located at $04^{\circ} 00^{\prime} 18^{\prime \prime}$ S, y $69^{\circ} 54^{\prime} 45^{\prime \prime} \mathrm{W}$, altitude $146 \mathrm{~m}$.

Three different environments within the Amazon rain forest were surveyed: a firm land forest (L), a flood plain forest (F) and a white sand forest (W). In each site, three traps made from plastic PET bottles (Figure 1, further details in Ferreira, 1978) were set up $2 \mathrm{~m}$ above ground along a transect of $1500 \mathrm{~m}$. Traps were baited with a one day old fish head in decomposition and specimens were collected every 12 hours during a period of 48 hours. Species accumulation curves and non-parametric estimators of total species richness ICE and Chao2 generated by StimateS 7.5 (Colwell, 2005) to assess the sampling efficiency and representatition of the sampling. Kruskall-Wallis test were used for difference in abundance and richness among habitat. Specimens were identified using Chillcott (1961), Guimarães (1977), Couri \& Winagraski (2005), Amat et al (2008) and Pape \& Dahlem (in press). Specimens were deposited in the entomological collection of the Instituto Alexander von Humboldt [IAvH] Villa de Leiva, Boyacá, Colombia.

A total of 1266 flies representing 19 species and 4 families was recorded. Calliphoridae was the most abundant family $(\mathrm{N}=693,54.7 \%)$, while Sarcophagidae showed the highest species richness values ( 8 species). The most abundant
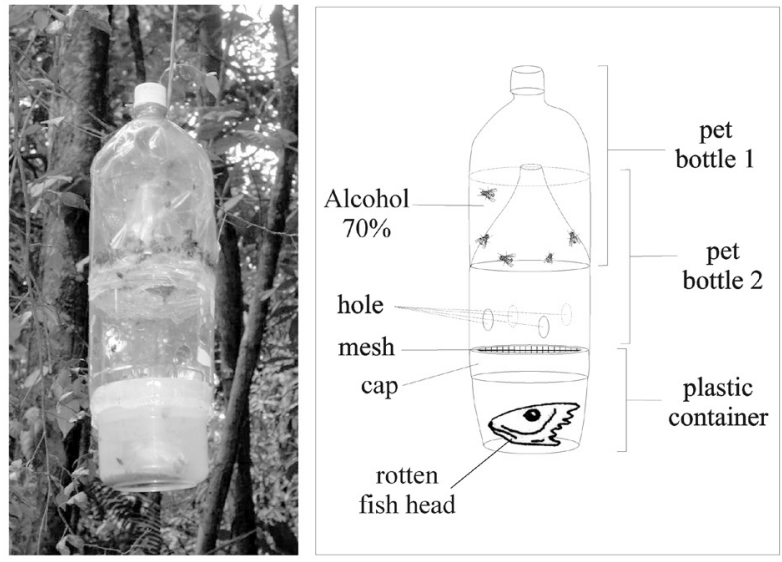

Figure 1 - The modified trap model proposed by Ferreira (1978) for fish carrion feeding flies.

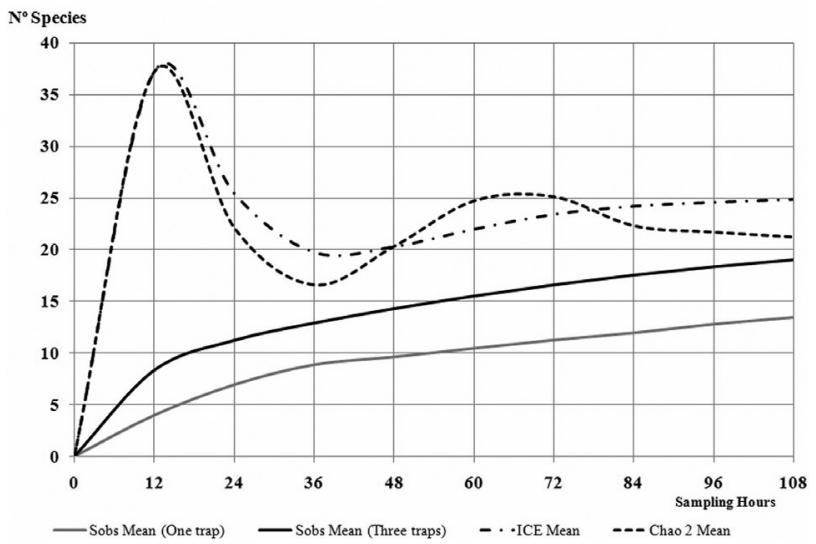

Figure. 2 - Species accumulation curve for observed necrophagous flies using three modified traps (black line) versus a single trap (gray line); and values of two incidence-based estimators Chao (dash line) and ICE (dash pointed line) along three different environments in Colombian Amazon

species was Chloroprocta idioidea (N=540, 42\%) and this report is consistent with findings by Esposito (1999) in Brazilian Amazon. Fourteen species ( $\mathrm{N}=431$ individuals) were found associated with flood land forest, 13 species $(\mathrm{N}=583$ individuals) with firm land forest and 14 species $(\mathrm{N}=297$ individuals) with white land forest.

Eight species (42\%) were found in all the sites, 6 species (31\%) were found in two sites and 5 species $(21 \%)$ were present in only one site. Approximately $71 \%$ of specimens were females (Table. 1).

Additionaly, this is the first record of Mesembrinella batesi (Aldrich, 1922) and Fannia femoralis (Stein, 1897) in Colombia, which were collected in our study. Dissection of male genitalia from Fannia sp. 1 revealed that the specimens did not match any previous description, what suggest that this species is possibly a new. 
Table 1. Decomposer flies associated with fish carrion in three different environment of Amazon rain forest of Colombia from 03 to 13 December 2007 . F: Flood plain forest; L: Firm land forest; W: White sand forest.

\begin{tabular}{|c|c|c|c|c|c|}
\hline Family & Genus/species & Site & $\mathrm{N}^{0}$ males & $\mathrm{N}^{0}$ females & Total Abundance \\
\hline \multirow[t]{5}{*}{ Calliphoridae } & Chloroprocta idioidea (Robineau-Desvoidy), 1830 & All & 290 & 250 & 540 \\
\hline & Eumesembrinella randa (Walker, 1849) & All & 20 & 93 & 113 \\
\hline & Hemilucilia semidiaphana (Rondani, 1850) & All & 22 & 26 & 28 \\
\hline & Mesembrinella batesi (Aldrich, 1922) & All & 2 & 8 & 10 \\
\hline & Mesembrinella sp.1 & $\mathrm{L} / \mathrm{F}$ & 0 & 2 & 2 \\
\hline \multirow[t]{3}{*}{ Fannidae } & Fannia femoralis (Stein, 1897) & All & 8 & 146 & 154 \\
\hline & Fannia obscurinervis (Stein, 1900) & All & 8 & 112 & 116 \\
\hline & Fannia nov sp 1 & $\mathrm{~L} / \mathrm{F}$ & 3 & 8 & 11 \\
\hline \multirow[t]{3}{*}{ Muscidae } & Genus sp. 1 & All & 25 & 212 & 237 \\
\hline & Genus sp. 2 & F/W & 0 & 3 & 3 \\
\hline & Genus sp. 3 & $\mathrm{~F} / \mathrm{W}$ & 0 & 2 & 2 \\
\hline \multirow[t]{8}{*}{ Sarcophagidae } & Genus sp. 3 & All & 0 & 20 & 20 \\
\hline & Genus sp. 1 & L & 0 & 13 & 13 \\
\hline & Oxysarcodexia sp. & W & 0 & 8 & 8 \\
\hline & Peckia sp.1 & L/W & 0 & 3 & 3 \\
\hline & Peckia subducta (Lopes, 1935) & $\mathrm{F} / \mathrm{W}$ & 2 & 0 & 2 \\
\hline & Genus sp. 2 & L & 1 & 1 & 2 \\
\hline & Lepidodexia latifrons (Kano \& Lopes, 1969) & W & 1 & 0 & 1 \\
\hline & Engelimyia inops (Walker, 1849) & $\mathrm{F}$ & 1 & 0 & 1 \\
\hline
\end{tabular}

For the non-parametric ICE and Chao 2 indexes we estimated a total of 22 and 20 species respectively, and observed (a conservative richness of 19) that S was higher than previously reported for carrion fly communities (up to 10 common species; Ives, 1991). According to these indexes, we conclude that few species $(10 \%$ according most strict estimator) were not collected by this trapping method. We suggest that more than 108 hours of trapping effort or more traps are necessary for assessing similar transects and habitats. There was no significant difference in abundance (Kruskall-Wallis, $\mathrm{P}=0.983$ ) or richness (Kruskall-Wallis, $\mathrm{P}=0.462$ ) among the three sites. Apparently these families with species of high dispersion capacity (Greenberg, 1973) do not show fidelity according to the type of habitat within the forest. However, most of the Calliphoridae, Sarcophagidae and Fannidae species collected were reported as asynantropic except for Fannia obscurnervis, which prefers environments inhabited by man (Carvalho, 2002). Our results suggest that there is a high number of species making up the carrion fly community and possibly they are restricted to continuous and preserved areas of rain forest. These species have a high rate of dispersion and broad habitat preferences. Unfortunately, there is no information available about synantropic flies in closed urban environments (around the cities of Leticia and Tabatinga) to make relevant local comparisons. Many physical, ecological and biological factors will affect the assemblage patterns of these complex communities (Hanski, 1987) which remain largely unknown for most habitat in the Amazonian forest.

\section{ACKNOWLEDGEMENTS}

I thank Mauricio Alvarez from the Instituto de Investigación de Recursos Biológicos Alexander von Humboldt; Maria Cristina Peñuela from the Universidad Nacional de Colombia, Sede Leticia and the director of the Biological Station "El Zafire" for logistics support; Luis Edier Franco, Ever Kuiro and Sara Milena Florez for their assistance during field work; Eliana Buenaventura for her valuable help sorting and identifying flesh flies. Thomas Pape, Orou Gaoue and two anonymous reviewers for manuscript suggestions. 


\section{LITERATURE CITED}

Amat, E., M. C. Vélez. y M. Wolff. 2008. Illustrated key for identification to genera and species of blowflies (Diptera: Calliphoridae) of Colombia. Caldasia 30: 231-244. (in Spanish, with abstract in English).

Baumgartner, D. \& Greenberg, B. 1984. The genus Chrysomya (Diptera: Calliphoridae) in the New World. J. Med . Entomol. 21: 105-113

Carvalho, C.J.B de; M.O. Moura \& P.B. Ribeiro. 2002. Key to adult flies of dipterous species (Muscidae, Fanniidae, Anthomyiidae) associated to human settled in Brasil. Revista Brasileira de Entomologia 46(2):107-114. (in Portuguese, with abstract in English).

Carvalho, C.J.B. de; A.C.Pont; M.S. Couri \& D. Pamplona. 2003. A Catalogue of the Faniidae (Diptera) of the Neotropical Region. Zootaxa. Auckland, 219:1-32

Chillcott, J. G. 1961. A revision of the Neartic species of Fanniinae (Diptera: Muscidae).Canadian Entomologist Supplement 14: 1-295.

Colwell, R.K. 2005. EstimateS: Estatistical stimation of species richness and shered species from samples, Version 7.5. Persistent URL<purl.oclc.org/estimates $>$.

Couri, M.S \& Winagraski, E. 2005. New Fannia Robineau-Desvoidy from Amazonas, Brazil and new geographical record (Diptera, Fanniidae). Revista Brasilera de Zoologia 22 (3):645-647

Esposito, M.C. 1999. The Blowfly (Diptera:Calliphoridae) fauna of the Amazon basin, and its Ecology in Caixuaná region and Portel town/State of Pará. Tese para obtenção do titulo de doutor, Instituto Nacional de Pesquisas da Amazônia. Manaus, Amazonas, Brasil. 133p. (in Portuguese).

Ferreira, J.M. de M. 1978. Synantropy of muscoids dipterous from Curitiba, Paraná. I. Calliphoridae. Revista. Brasilera de Biologia. 38(2):445-454. (in Portuguese, with abstract in English).

Greenberg, B. 1973. Flies and disease. Vol 2. Princeton Univ. Press. NJ.447 p.
Guimarães, J.H. 1977. A systematic revision of the Mesembrinellidae, stat. nov. (Diptera, Cyclorrhapha). Arquivos de Zoologia. 29: 1-109.

Hanski, I. 1987. Carrion fly community dynamics: patchiness, seasonality and coexistence. Ecological Entomology. 12, 257-266

Ives, A.R. 1991. Aggregation and Coexistence in a Carrion Fly Community. Ecological Monographs, Vol. 61, No. 1: 75-94.

Nuorteva, P. 1977. Sarcosaprophagous insects as forensic indicators, in: C.G. Tedeschi; W.G. Eckert; L.G. Tedeschi (Eds). Forensic Medicine: A study of Trauma and Environmental Hazards, Vol. II, W. B. Saunders Co., Philadelphia, p. 1072-1095.

Pape, T. \& Dahlem, G.A. Sarcophagidae. In: Brown, B.V., Borkent, A., Cumming, J.M., Wood, D.M., Woodley, N.E. \& Zumbado, M. (eds), Manual of Central American Diptera. Vol. 2. NRC Press, Ottawa. [In press.]

Pape, T., Wolff, M. \& Amat, E. 2004. The blow flies, bot flies, woodlouse flies and flesh flies (Diptera: Calliphoridae, Oestridae, Rhinophoridae, Sarcophagidae) of Colombia. Biota Colombiana. 5:201-208.

Paraluppi, N. D. 1991. Calliphoridae (Diptera) of Manaus: Taxonomy, seasonality, flight activity, ovarian development and disease vector potentiality in outdoor markets. Tese, Instituto Nacional de Pesquisas da Amazônia. Manaus, Amazonas, Brasil. 123p. (in Portuguese).

Richards, E. N. 2001. Spatial and temporal variation in carrion Blow Fly Communities. PhD dissertation. Texas Tech University. Texas. USA. 256pp. http://etd.lib.ttu.edu/theses/available/etd07312008-31295017082552/

Recebido em 02/02/2009

Aceito em 09/12/2009 